\title{
McDonough Condemns Proposed Federal Budget Guts for Libraries
}

"Proposed cuts in the federal budget for aid to libraries would result in drastically reduced funds being available for public libraries, school libraries, and other types of libraries. Library services to the public would inevitably suffer," David H. Clift, Executive Director of the American Library Association, said in Chicago April 21. He firmly endorsed the views expressed earlier by Roger $H$. McDonough, President of the American Library Association, at a press conference in New York City.

Mr. McDonough, who is Director of the New Jersey State Library, condemned the proposed budget slashes in the federal budget for aid to education and libraries as recommended in the President's April 15th message to Congress. Mr. MeDonough spoke at a press conference held at the Overseas Press Club in New York City.

Noting that the reductions in library programs amount to fully 25 per cent of the total cuts, Mr. McDonough termed it "ironic that the release of these recommendations ap-

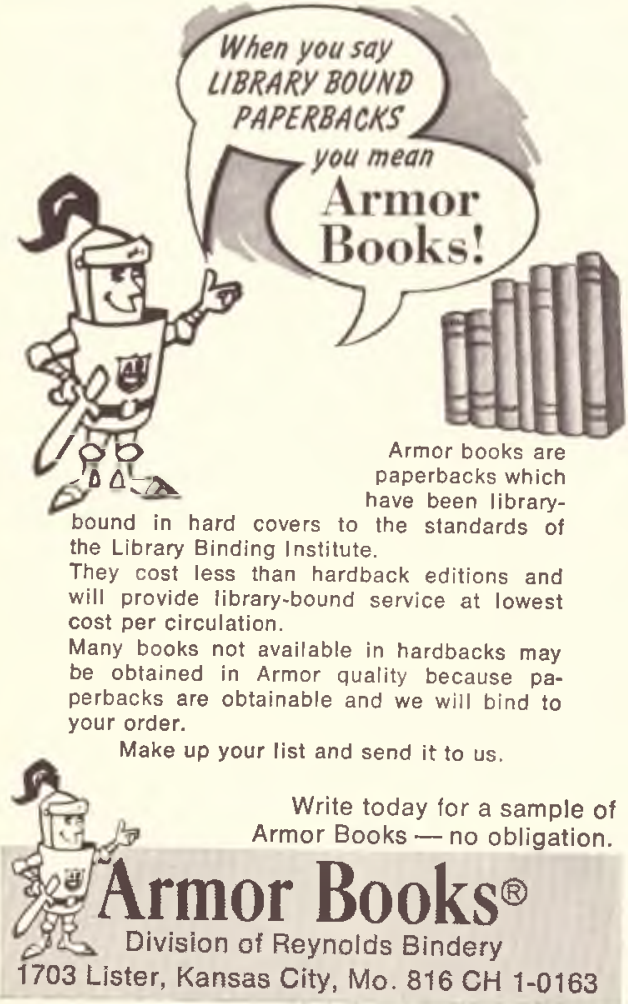

peared almost simultaneously with the President's National Library Week message in which he said '... never have our libraries played a more prominent role in our campaign against ignorance and for fullness of educational opportunity . . . by extending their services throughout America, our libraries immeasureably advance our goals and perform the highest public good.'

"But according to the Undersecretary of Health, Education and Welfare," Mr. McDonough continued, "programs for books and equipment are considered 'low priority.' This is clearly a misunderstanding or misinterpretation of the manner in which these funds have been employed.

"Under Title II of the Elementary and Secondary Education Act, for example, spectacular advances have been made in the improvement of school libraries and instructional media centers. The threatened cuts will seriously curtail the amount and quality of materials made available to all schools, public and private, and will be particularly damaging to those schools serving disadvantaged youth in our inner-core cities.

"The cutbacks proposed in Title I of the Library Services and Construction Act will seriously cripple innovative outreach library programs to urban poor, migrant workers and other disadvantaged groups in all parts of the country.

"The 1970 Johnson Budget request for major library programs-ESEA Title II, Higher Education Act Title II, and LSCA-amounted to $\$ 134,500,000$. The new recommendations, if accepted by Congress, would provide only $\$ 46,209,000$, which is $\$ 88,291,000$ less than the January budget and $\$ 433,891,000$ less than the amounts authorized for these programs in fiscal year 1970 (beginning July 1,1969 ).

"Looking at it another way, almost twentyfive per cent of the recommended reductions in funding for activities under the Office of Education would come out of the principal library programs. Keep in mind, too, that this does not take into consideration the money already lopped off by the January budget proposal, which cut out NDEA Title III (equipment and instructional materials) and HEA Title VI (equipment and materials for higher education), both of which benefited library users. The 1969 appropriations for Title III was $\$ 78,740,000$, and for Title VI it was $\$ 14,500,000$. As it now stands, these programs would be terminated. 
Title II-School Library Resources, Textbooks, and Other Instructional Materials

Library Services and Construction Act

Title I-Public Library Services

Title II-Public Library Construction

Title III-Interlibrary Cooperation

Title IVA-State Inst. Library Servs.

Title IVB-L. Servs. to the Phy. Handicapped

Higher Education Act

Title II-College Library Assistance and Library Training and Research

Part A-College Library Resources

Part B-Lib. Training, including Institutes -Research

Part C-LC Acquisition and Cataloging

"If no effort is made to override these recommended cuts, the prospects for even minimal aid for library resources for school, public and academic library users will be dismal indeed. There will be no funds at all for the school library program under Title II of the Elementary and Secondary Education Act. Half of the Title I funds for public library services and all of the Title II construction money will be withdrawn from programs partially supported by the Library Services and Construction Act. And half of the college library resources fund will be cut out of the HEA Title II-A program, leaving only enough money to make basic grants of $\$ 5,000$; training opportunities for librarians will be reduced by more than fifty per cent under Title II-B; and the Library of Congress acquisition and cataloging activities now assisted by the Title II, Part C program will be reduced by $\$ 2,856,000$."

\section{LIBRARY TECHNOLOGY PROGRAM MARKS 10TH ANNIVERSARY}

May marks the 10th anniversary of the Library Technology Program of the American Library Association. In a statement issued on the occasion, Forrest F. Carhart, Jr., director of the Library Technology Program, said, "I am proud of the accomplishments of the Library Technology Program over the past 10 years. LTP has, I believe, made many worthwhile contributions to the library community in the areas of testing, research, publishing, invention, standards and product evaluation. In a profession," he continued, "that 10 years ago had few guidelines or tools available to help the librarian make decisions on technical matters, cooperation.
$-0$

$\$ 23,209,000$

$\$ 17,500,000$

-0 -

$2,281,000$

$2,094,000$

$1,334,000$

$\$ 42,000,000$

$\$ 200,000,000$

$\$ 49,894,000$

$\$ 35,000,000$

$9,185,000$

$2,281,000$

$2,094,000$

$1,334,000$

$\$ 166,000,000$

$\$ 65,000,000$

$70,000,000$

$12,500,000$

$12,500,000$

$6,000,000$

$\left.\begin{array}{c}\$ 23,000,000 \\ 12,500,000 \\ 4,000,000 \\ 2,000,000 \\ 4,500,000\end{array}\right\}$

$\$ 42,606,000$

$25,000,000$

$8,250,000$

$2,000,000$

$7,356,000$
$\$ 114,100,000$

$75,000,000$

$28,000,000$

$11,100,000$

LTP has made a significant impact. Its work is now known in many countries of the world-as nearby as Canada, as distant as Australia. It gives assistance and information free-and freely-to all who seek its help, whether it concerns a $\$ 1,000$ expenditure on audiovisual equipment, or the manufacture of rustproof paper clips."

Carhart recalled that the idea of a technical project to serve the needs of the library world originated with the Council on Library Resources, Inc., and out of this idea grew a proposal that the Council undertake a researchtesting-standardization program in the field of library supplies, equipment, and systems. A grant of $\$ 136,395$ from the Council transformed the idea into a reality on May 1, 1959. "How well the idea and the reality have matured is seen today in the range of LTP's activities," continued Carhart. "They encompass an information service, a subscription service, the development of standards, product development and testing, publishing and international

"On this 10th anniversary of the Library Technology Program, I am particularly proud that we have been able to stimulate industry to bring to the market place products that answer the needs of librarians. We have done this in many ways, from speeches and informal talks, to marketing our own LTP inventions. I am proud, too, of Library Technology Reports, that every two months brings to subscribers much important information about products, and current technological news of interest to librarians. Its impact on the profession and on the library equipment and supplies manufacturing industry has been considerable, bringing with it an awareness by both groups of the need for better quality products and more intelligent purchasing. In another area," he 